\title{
Ponticoccus litoralis gen. nov., sp. nov., a marine bacterium in the family Rhodobacteraceae
}

Correspondence

Byung Cheol Cho

bccho@snu.ac.kr

\section{Chung Yeon Hwang and Byung Cheol Cho}

School of Earth and Environmental Sciences and Research Institute of Oceanography, Seoul National University, San 56-1, Shillim-dong, Kwanak-gu, Seoul 151-742, Republic of Korea

\begin{abstract}
A Gram-negative, coccoid to rod-shaped, strictly aerobic bacterium, strain CL-GR66 ${ }^{\top}$, was isolated from coastal seawater collected off Korea. The strain grew optimally in the presence of $3-5 \%$ sea salts, at a temperature of $30{ }^{\circ} \mathrm{C}$ and at $\mathrm{pH}$. The polar lipid profile of strain CLGR66 ${ }^{\top}$ comprised phosphatidylcholine, phosphatidylglycerol, phosphatidylethanolamine, two unidentified aminolipids, an unidentified glycolipid and an unidentified lipid. The major fatty acids were $\mathrm{C}_{18: 1} \omega 7 c(71.4 \%), 11$-methyl $\mathrm{C}_{18: 1} \omega 7 c(11.3 \%), \mathrm{C}_{16: 0}(6.4 \%), \mathrm{C}_{18: 0}(4.6 \%)$ and $\mathrm{C}_{12: 1} 3-\mathrm{OH}$ (3.0\%). Ubiquinone 10 was the major quinone. The DNA G+C content was 67.9 mol\%. 16S rRNA gene sequence analysis revealed that strain CL-GR66 ${ }^{\top}$ belonged to the Roseobacter clade within the family Rhodobacteraceae. Strain CL-GR66 ${ }^{\top}$ was related most closely to the type strain of Marinovum algicola (95.5\% 16S rRNA gene sequence similarity), and sequence similarities between strain CL-GR6 ${ }^{\top}$ and other type species of the Roseobacter clade ranged from 91.8 to $95.4 \%$. Phylogenetic analyses of $16 \mathrm{~S}$ rRNA gene sequences showed that strain CL-GR66 ${ }^{\top}$ was not associated with any known genus in the family Rhodobacteraceae. The distinct phylogenetic position of strain $\mathrm{CL}-\mathrm{GR} 66^{\top}$, its phylogenetic distance from genera of the family Rhodobacteraceae, together with phenotypic data, suggest that the organism represents a novel species of a new genus, for which the name Ponticoccus litoralis gen. nov., sp.

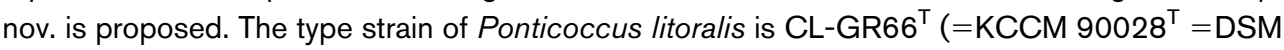
$\left.18986^{\top}\right)$.
\end{abstract}

The Roseobacter clade, which was named after the genus Roseobacter by Giovannoni \& Rappé (2000), is classified within the family Rhodobacteraceae, which in turn belongs to subgroup 3 of the Alphaproteobacteria (Woese et al., 1984). At the time of writing, this clade contains more than 35 genera (Buchan et al., 2005). Bacterial species affiliated with the Roseobacter clade have been isolated from various marine environments, such as seawater, sediment, marine algae, hypersaline microbial mats and marine biofilms (Buchan et al., 2005; Choi \& Cho, 2006a; Dai et al., 2006). Their physiological properties are highly diverse, including aerobic anoxygenic photosynthesis, aerobic sulfite oxidation, organic sulfur compound degradation, lignin degradation, methylotrophy and antibiotic production (Buchan et al., 2005; Martens et al., 2006). Here we

Abbreviation: $\mathrm{PHB}$, poly- $\beta$-hydroxybutyrate.

The GenBank/EMBL/DDBJ accession number for the 16S rRNA gene sequence of strain $\mathrm{CL}-\mathrm{GR} 66^{\top}$ is EF211829.

A transmission electron micrograph of negatively stained cells, twodimensional TLCs of polar lipids, an extended neighbour-joining tree derived from 16S rRNA gene sequences and a table detailing the cellular fatty acid composition of strain CL-GR66 ${ }^{\top}$ and phylogenetically related genera in the family Rhodobacteraceae are available as supplementary material with the online version of this paper. describe a bacterial strain isolated from coastal seawater that was characterized based on a polyphasic approach (Vandamme et al., 1996). On the basis of its chemotaxonomic, physiological and phylogenetic characteristics, we propose that this bacterium represents a novel species of a new genus in the family Rhodobacteraceae.

A coastal water sample was incubated with sand sediment in a $150 \mathrm{~mm}$-diameter glass Petri dish at room temperature for approximately 15 months. Without disturbing the sediment, $100 \mu \mathrm{l}$ surficial seawater was taken and spread on a marine agar 2216 (MA; Difco) plate, which was then incubated at $30{ }^{\circ} \mathrm{C}$ for 1 week. Strain CL-GR66 ${ }^{\mathrm{T}}$ was isolated and subsequently purified four times on MA at $30{ }^{\circ} \mathrm{C}$. The strain was maintained both on MA at $30{ }^{\circ} \mathrm{C}$ and in marine broth 2216 (MB; Difco) supplemented with $30 \%$ (v/v) glycerol at $-80{ }^{\circ} \mathrm{C}$.

Morphological and physiological tests were performed as follows. Gram staining was performed according to Smibert \& Krieg (1994). Cell motility was observed via the hanging-drop method (Suzuki et al., 2001). Cell morphology and the presence of flagella were observed by transmission electron microscopy (EX2; JEOL). Anaerobic growth was checked on MA and ZOF medium (Lemos et al., 1985) supplemented with additional agar 
$(1.5 \%)$ by using the GasPak anaerobic system (BBL) at $30{ }^{\circ} \mathrm{C}$ for 15 days. Poly- $\beta$-hydroxybutyrate (PHB) granules were observed by epifluorescence microscopy (BX60; Olympus) after Nile blue A staining (Ostle \& Holt, 1982). Bacteriochlorophyll $a$ production was determined in $90 \%$ acetone extracts with a spectrophotometer (Ultraspec 2000; Pharmacia Biotech) for cells that had been grown in either the light or the dark for 7 days. The presence of photosynthetic reaction-centre genes pufL and puf $M$ was determined by using PCR amplification with gene-specific primers (Allgaier et al., 2003) for strain CLGR66 ${ }^{\mathrm{T}}$, with Porphyrobacter donghaensis $\mathrm{SW}-132^{\mathrm{T}}$ $\left(=\right.$ KCTC $12229^{\mathrm{T}}$; Yoon et al., 2004) as a positive control.

The temperature range for growth was examined on the basis of colony formation on MA incubated at temperatures ranging from 5 to $40{ }^{\circ} \mathrm{C}$, in increments of $5{ }^{\circ} \mathrm{C}$. The $\mathrm{pH}$ range (5-10, in increments of $1 \mathrm{pH}$ unit) for growth was determined by assessing changes in $\mathrm{OD}_{600}$ over the incubation period (up to 7 days) in $\mathrm{MB}$ at $30{ }^{\circ} \mathrm{C}$. The final $\mathrm{pH}$ was adjusted by using $1 \mathrm{M} \mathrm{NaOH}$ and $1 \mathrm{M} \mathrm{HCl}$. Tolerance of strain CL-GR66 ${ }^{\mathrm{T}}$ to sea salts (Sigma) or $\mathrm{NaCl}$ was determined by assessing changes in $\mathrm{OD}_{600}$ in Zobell broth $(5 \mathrm{~g}$ Bacto peptone, $1 \mathrm{~g}$ yeast extract, $0.1 \mathrm{~g}$ ferric citrate, 11 distilled water) at sea salts or $\mathrm{NaCl}$ concentrations $(0-10 \%$ in increments of $1 \%$, and $15 \%, w / v)$ at $30{ }^{\circ} \mathrm{C}$.

Oxidase and catalase tests were performed according to the protocols described by Smibert \& Krieg (1994). Gelatinase, amylase and nitrate reductase activities and degradation of Tween 80 were determined according to Hansen \& Sørheim (1991). Other enzyme activities were assayed by using the API ZYM kit (bioMérieux) according to the manufacturer's instructions, except that the cell suspension was prepared by using artificial seawater $(24 \mathrm{~g} \mathrm{NaCl}, 5.1 \mathrm{~g}$ $\mathrm{MgCl}_{2}, 4 \mathrm{~g} \mathrm{Na}_{2} \mathrm{SO}_{4}, 1.1 \mathrm{~g} \mathrm{CaCl}_{2}, 0.7 \mathrm{~g} \mathrm{KCl}, 0.2 \mathrm{~g} \mathrm{NaHCO}_{3}$, $0.1 \mathrm{~g} \mathrm{KBr}, 0.027 \mathrm{~g} \mathrm{H}_{3} \mathrm{BO}_{3}, 0.024 \mathrm{~g} \mathrm{SrCl}_{2}, 0.003 \mathrm{~g} \mathrm{NaF}, 1 \mathrm{l}$ distilled water; Lyman \& Fleming, 1940). Carbon utilization was tested by using basal broth medium supplemented with yeast extract $(23.6 \mathrm{~g} \mathrm{NaCl}, 0.64 \mathrm{~g} \mathrm{KCl}, 4.53 \mathrm{~g}$ $\mathrm{MgCl}_{2} \cdot 6 \mathrm{H}_{2} \mathrm{O}, 5.94 \mathrm{~g} \mathrm{MgSO}_{4} \cdot 7 \mathrm{H}_{2} \mathrm{O}, 1.3 \mathrm{~g} \mathrm{CaCl} .2 \mathrm{H}_{2} \mathrm{O}$, $0.2 \mathrm{~g} \mathrm{NaNO}_{3}, 0.2 \mathrm{~g} \mathrm{NH}_{4} \mathrm{Cl}, 0.05 \mathrm{~g}$ yeast extract, $1 \mathrm{l}$ distilled water; Bruns et al., 2001) containing $0.4 \%$ carbon source. Strain CL-GR66 ${ }^{\mathrm{T}}$ was incubated for 4 weeks and carbon utilization was scored as negative when the growth rate was equal to or less than that in the negative control with no carbon source. Growth rate was measured by monitoring changes in $\mathrm{OD}_{600}$. Resistance to antibiotics was determined by the disc-diffusion plate method (Bauer et al., 1966).

Polar lipids were extracted by using the procedures described by Minnikin et al. (1984) and were identified by two-dimensional TLC followed by spraying with appropriate detection reagents (Komagata \& Suzuki, 1987). Fatty acid methyl esters in whole cells of strain CL-GR66 ${ }^{\mathrm{T}}$ grown on MA at $30{ }^{\circ} \mathrm{C}$ for 4 days were analysed by GC according to the instructions of the Microbial Identification System (MIDI) at the Korean Culture Center of Microorganisms (KCCM), Seoul, Korea. The quinone system was determined according to Minnikin et al. (1984) and analysed by HPLC as described by Collins (1985). The DNA G +C content was analysed by HPLC (HP 100; Hewlett Packard) analysis of deoxyribonucleosides as described by Mesbah et al. (1989), after DNA extraction according to the method of Marmur (1961). Lambda DNA was used as a standard.

For 16S rRNA gene amplification by PCR, DNA was extracted from a single colony via a boiling method (Englen \& Kelley, 2000). The crude extracts served as template DNA. Taq DNA polymerase (Bioneer) and primers 27F and 1492R (Lane, 1991) were used for PCR experiments. The PCR product was purified by using the AccuPrep PCR purification kit (Bioneer) and direct sequence determination of the purified 16S rRNA gene was performed with an Applied Biosystems automated sequencer (ABI3730XL) at Macrogen, Seoul, Korea. The almost-complete 16S rRNA gene sequence of strain CLGR66 $^{\mathrm{T}}$ (1357 nt) was obtained and compared with available $16 \mathrm{~S}$ rRNA gene sequences in GenBank by using BLASTN searches (Altschul et al., 1990). The sequence of strain CL-GR66 ${ }^{\mathrm{T}}$ was manually aligned with those of species in the family Rhodobacteraceae, obtained from the GenBank and Ribosomal Database Project (Cole et al., 2003) databases, using known 16S rRNA secondarystructure information. Phylogenetic trees were obtained by using the neighbour-joining (Saitou \& Nei, 1987) and maximum-parsimony (Fitch, 1971) methods. An evolutionary distance matrix for the neighbour-joining method was generated according to the model of Jukes \& Cantor (1969). The robustness of tree topologies was assessed by bootstrap analyses based on 1000 replications for the neighbour-joining and maximum-parsimony methods. Alignment analysis was carried out by using the jPHYDIT program (Jeon et al., 2005), and phylogenetic analyses were carried out by using MEGA 3 (Kumar et al., 2004).

Cells of strain CL-GR66 ${ }^{\mathrm{T}}$ were Gram-negative, coccoid to rod-shaped and approximately $0.5-0.8 \mu \mathrm{m}$ wide and $0.8-$ $1.2 \mu \mathrm{m}$ long (see Supplementary Fig. S1 in IJSEM Online). The cells were non-motile. After 3 days on MA at $30{ }^{\circ} \mathrm{C}$, colonies were creamy and approximately $2 \mathrm{~mm}$ in diameter. Strain CL-GR66 ${ }^{\mathrm{T}}$ was strictly aerobic (Table 1) and contained PHB granules. Bacteriochlorophyll $a$ and the pufL and pufM genes were not detected. Other phenotypic characteristics of strain CL-GR66 ${ }^{\mathrm{T}}$ are given in the genus and species descriptions and in Table 1.

The polar lipid profile of strain CL-GR66 ${ }^{\mathrm{T}}$ comprised phosphatidylcholine, phosphatidylglycerol, phosphatidylethanolamine, an unidentified glycolipid, two unidentified aminolipids and an unidentified lipid (Supplementary Fig. S2). The predominant fatty acid of strain CL-GR66 ${ }^{\mathrm{T}}$ was $\mathrm{C}_{18: 1} \omega 7 c(71.4 \%)$, which is a feature of the vast majority of species within the Alphaproteobacteria (Martens et al., 2006), followed by 11-methyl $\mathrm{C}_{18: 1} \omega 7 c(11.3 \%), \mathrm{C}_{16: 0}$ $(6.4 \%), \mathrm{C}_{18: 0} \quad(4.6 \%)$ and $\mathrm{C}_{12: 1} \quad 3-\mathrm{OH} \quad(3.0 \%)$ 
Table 1. Selected characteristics that differentiate strain $\mathrm{CL}-\mathrm{GR} 66^{\top}$ from related genera in the family Rhodobacteraceae

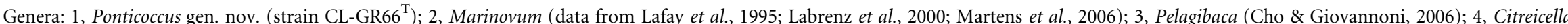

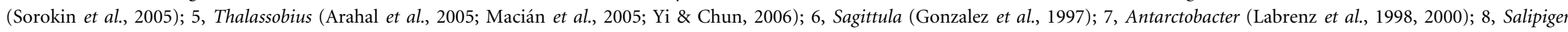

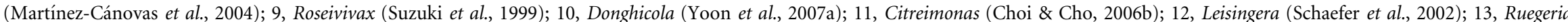

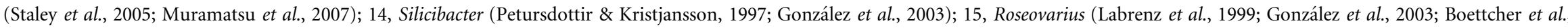

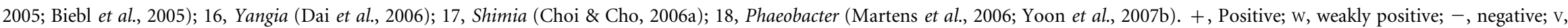
variable; ND, no data available; BChl, bacteriochlorophyll.

\begin{tabular}{|c|c|c|c|c|c|c|c|c|c|c|c|c|c|c|c|c|c|c|}
\hline Characteristic & 1 & 2 & 3 & 4 & 5 & 6 & 7 & 8 & 9 & 10 & 11 & 12 & 13 & 14 & 15 & 16 & 17 & 18 \\
\hline Species $(n)$ & 1 & 1 & 1 & 1 & 3 & 1 & 1 & 1 & 2 & 1 & 1 & 1 & 2 & 2 & 4 & 1 & 1 & 3 \\
\hline Cell morphology* & $\mathrm{C}-\mathrm{R}$ & $\mathrm{O}-\mathrm{R}$ & SR & $\mathrm{O}-\mathrm{SR}$ & $\mathrm{O}-\mathrm{IR}$ & $\mathrm{R}$ & $\mathrm{R}$ & $\mathrm{R}$ & $\mathrm{R}$ & $\mathrm{C}-\mathrm{R}$ & OR & $\mathrm{R}-\mathrm{OR}$ & $\mathrm{R}-\mathrm{OR}$ & $\mathrm{R}$ & $\mathrm{R}-\mathrm{O}$ & $\mathrm{R}$ & $\mathrm{R}$ & OR \\
\hline Colony colour $†$ & $\mathrm{C}$ & $\mathrm{BG}, \sim \mathrm{P}$ & $\mathrm{C}$ & wH & SP or C & C & BRY & C & $\mathrm{P}$ & I & BG & - & BG & BG & C, BG-PBG, R & FY & BG & $\mathrm{BR},-$ \\
\hline Anaerobic growth & - & - & + & - & - & - & - & - & - & - & - & - & - & - & - & - & - & - \\
\hline Motility & - & + & - & - & V & - & V & - & + & - & - & + & $\mathrm{V}$ & + & V & + & + & + \\
\hline \multicolumn{19}{|l|}{ Growth at: } \\
\hline $4{ }^{\circ} \mathrm{C}$ & - & - & - & - & $\mathrm{V}$ & - & + & - & ND & - & - & - & - & - & $\mathrm{v}$ & - & - & $\mathrm{V}$ \\
\hline $37{ }^{\circ} \mathrm{C}$ & + & + & + & - & + & + & + & + & $\mathrm{ND}$ & + & + & - & - & + & + & + & - & $\mathrm{v}$ \\
\hline Nitrate reduction & + & - & + & - & $\mathrm{V}$ & - & + & - & $\mathrm{v}$ & + & + & - & + & - & $\mathrm{V}$ & - & + & $\mathrm{V}$ \\
\hline \multicolumn{19}{|l|}{ Hydrolysis of: } \\
\hline Starch & + & $\mathrm{W}$ & ND & ND & - & - & $\mathrm{V}$ & - & - & - & - & + & - & - & - & - & + & - \\
\hline Gelatin & + & + & + & $-\ddagger$ & $\mathrm{V}$ & - & + & - & $\mathrm{V}$ & - & + & ND & - & + & - & - & + & - \\
\hline РHB & + & - & - & + & + & + & + & + & ND & $\mathrm{ND}$ & + & ND & - & - & $\mathrm{ND}$ & + & - & $\mathrm{ND}$ \\
\hline BChl $a$ & - & - & - & - & + & - & - & - & + & - & - & $\mathrm{ND}$ & - & - & $\mathrm{V}$ & - & - & + \\
\hline \multicolumn{19}{|l|}{ Utilization of: } \\
\hline Succinate & - & - & + & + & ND & + & + & - & + & + & + & ND & + & + & + & $\mathrm{ND}$ & + & + \\
\hline Acetate & + & + & + & + & + & $\mathrm{ND}$ & + & - & + & + & + & - & ND & + & + & ND & - & V \\
\hline D-Glucose & + & + & + & + & + & + & + & - & + & + & + & - & + & v & + & - & - & + \\
\hline DNA $\mathrm{G}+\mathrm{C}$ content $(\mathrm{mol} \%)$ & 67.9 & $60-65$ & 65.4 & $67.5-69.2$ & $57-61$ & 65.0 & $62-64$ & 64.5 & $59.7-64.4$ & 59.7 & 67.3 & 60.5 & $55-58.7$ & $66.2-68$ & $59-66$ & 63.3 & 57.2 & $55.7-64.9$ \\
\hline
\end{tabular}

${ }^{*}$, Cocci; O, ovoid; $\mathrm{R}$, rods; IR, irregular rods; OR, ovoid rods; SR, short rods.

$\dagger \mathrm{BG}$, Beige; BR, brown; BRY, brownish yellow; C, cream; FY, faint yellowish; I, ivory; P, pink; $\sim$ P, pinkish; PBG, pinkish beige; R, red; SP, salmon pink; wH, white; -, non-pigmented.

\$Data from Choi \& Cho (2006b). 


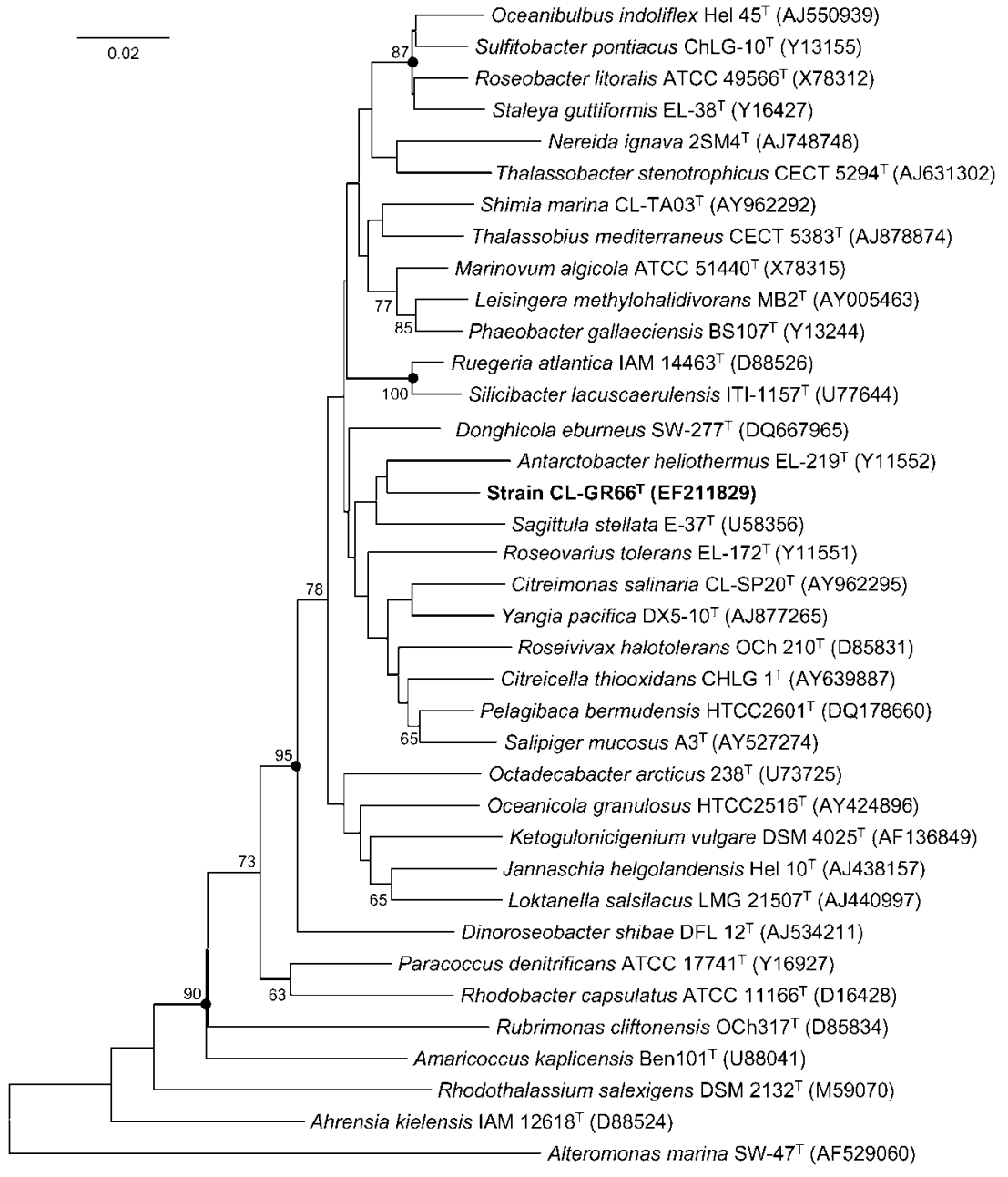

Fig. 1. Neighbour-joining tree derived from 16S rRNA gene sequences showing the phylogenetic position of strain CL-GR66 ${ }^{\top}$ and related members in the family Rhodobacteraceae. Bootstrap values (based on 1000 resamplings) are given at branch points; only values $>60 \%$ are shown. Solid circles indicate that the corresponding nodes were also recovered in the maximum-parsimony tree. Alteromonas marina SW- $47^{\top}$ was used as an outgroup. Bar, 0.02 nucleotide substitutions per site.
(Supplementary Table S1). The major isoprenoid quinone was ubiquinone 10. The DNA $\mathrm{G}+\mathrm{C}$ content was $67.9 \mathrm{~mol} \%$.

Analysis of the 16S rRNA gene sequence of strain CL${\text { GR } 66^{\mathrm{T}}}^{\mathrm{T}}$ revealed a clear affiliation with the Roseobacter clade in the family Rhodobacteraceae (Fig. 1). Strain CL-GR66 ${ }^{\mathrm{T}}$ was related most closely to the type strains of Marinovum algicola (95.5\% 16S rRNA gene sequence similarity), Pelagibaca bermudensis (95.4\%), Citreicella thiooxidans (95.3\%), Oceanicola batsensis (95.1\%), Thalassobius mediterraneus (95.1\%) and Sagittula stellata (95.0\%); levels of $16 \mathrm{~S}$ rRNA gene sequence similarity to the type strains of other type species of the Roseobacter clade were between 91.8 and $94.9 \%$. In spite of a rather high level of sequence similarity $(>95 \%)$ between strain CL-GR66 ${ }^{\mathrm{T}}$ and the type strains of the above species, strain CL-GR66 ${ }^{\mathrm{T}}$ did not form a robust clade with these or any other species in the Roseobacter lineage. In the phylogenetic tree including other genera in the family Rhodobacteraceae, strain CLGR66 ${ }^{\mathrm{T}}$ was weakly related to Antarctobacter and Sagittula (Fig. 1). Again, the cluster comprising the genera Antarctobacter and Sagittula plus strain CL-GR66 ${ }^{T}$ was not robustly supported in the phylogenetic tree in which most species in the family Rhodobacteraceae were included (Supplementary Fig. S3). Thus, strain CL-GR66 ${ }^{\mathrm{T}}$ formed a distinct lineage in all 16S rRNA gene sequence-based phylogenetic trees (Fig. 1, Supplementary Fig. S3). Given mean sequence divergence values of $>4.1 \%$ (SD $1.6 \%$; data not shown) among established genera of the Roseobacter clade, the observed sequence divergence of $>4.5 \%$ between strain CL-GR66 ${ }^{\mathrm{T}}$ and genera of this clade suggests that the lineage represented by strain CL-GR66 ${ }^{\mathrm{T}}$ is equivalent in rank to the genera of the Roseobacter clade.

In addition, several phenotypic and chemotaxonomic characteristics can be used to differentiate strain CLGR66 ${ }^{\mathrm{T}}$ from related genera in the family Rhodobacteraceae. Strain CL-GR66 ${ }^{\mathrm{T}}$ can be differentiated from members of the genus Antarctobacter based on the presence of 11methyl $\mathrm{C}_{18: 1} \omega 7 c(11.3 \%$; Supplementary Table S1) and the presence of phosphatidylethanolamine and an additional aminolipid (Supplementary Fig. S2; Labrenz et al., 1998). These taxa are also distinguished by the ability to grow at $4{ }^{\circ} \mathrm{C}$, different optimal temperature for growth (i.e. 30 and $16-26{ }^{\circ} \mathrm{C}$ for strain CL-GR66 ${ }^{\mathrm{T}}$ and Antarctobacter 
heliothermus, respectively) and utilization of succinate and L-rhamnose (Table 1; Labrenz et al., 1998). Strain CLGR66 $^{\mathrm{T}}$ is distinguishable from members of the genus Marinovum, including its closest phylogenetic relative, based on motility, the ability to reduce nitrate, PHB production and utilization of L-arabinose, myo-inositol, Llysine, D-mannitol and D-ribose (Table 1; Lafay et al., 1995). An additional aminolipid was uniquely detected in strain CL-GR66 ${ }^{\mathrm{T}}$, although phosphatidylcholine, phosphatidylglycerol, phosphatidylethanolamine and an unidentified aminolipid are commonly found in members of the genus Marinovum (Supplementary Fig. S2; Martens et al., 2006). In addition, combinations of phenotypic and chemotaxonomic characteristics can be used to differentiate strain CL-GR66 ${ }^{\mathrm{T}}$ from other related genera in the family Rhodobacteraceae (Table 1, Supplementary Table S1). The results of the present polyphasic study therefore indicate that strain CL-GR66 ${ }^{\mathrm{T}}$ represents a novel species of a new genus, for which the name Ponticoccus litoralis gen. nov., sp. nov. is proposed.

\section{Description of Ponticoccus gen. nov.}

Ponticoccus (Pon.ti.coc'cus. L. n. pontus the sea; N.L. masc. n. coccus berry; N.L. masc. n. Ponticoccus coccus from the sea).

Cells are Gram-negative, coccoid to rod-shaped. Nonmotile. Growth is strictly aerobic. Oxidase- and catalasepositive. Bacteriochlorophyll $a$ is not detected. Polar lipids are phosphatidylcholine, phosphatidylglycerol, phosphatidylethanolamine, an unidentified glycolipid, two unidentified aminolipids and an unidentified lipid. Dominant cellular fatty acids are $\mathrm{C}_{18: 1} \omega 7 c$, 11-methyl $\mathrm{C}_{18: 1} \omega 7 c$, $\mathrm{C}_{16: 0}, \mathrm{C}_{18: 0}$ and $\mathrm{C}_{12: 1} 3-\mathrm{OH}$. The isoprenoid quinone is Q-10. The DNA G + C content of the type strain of the type species is $67.9 \mathrm{~mol} \%$. Phylogenetically, the genus is a member of the family Rhodobacteraceae. The type species is Ponticoccus litoralis.

\section{Description of Ponticoccus litoralis sp. nov.}

Ponticoccus litoralis (li.to.ra'lis. L. masc. adj. litoralis of the shore).

Displays the following properties in addition to those given in the genus description. After 3 days on MA plates at $30{ }^{\circ} \mathrm{C}$, colonies are creamy and approximately $2 \mathrm{~mm}$ in diameter. Cells are approximately $0.5-0.8 \mu \mathrm{m}$ wide and $0.8-1.2 \mu \mathrm{m}$ long. Grows at $10-37{ }^{\circ} \mathrm{C}$ (optimum at $30{ }^{\circ} \mathrm{C}$ ) and $\mathrm{pH}$ 6-8 (optimum at $\mathrm{pH} 7$ ). Growth occurs at sea salt concentrations of $1-15 \%(\mathrm{w} / \mathrm{v})$ (optimum 3-5\%), but no growth occurs in media containing $\mathrm{NaCl}$ as the only salt. Cells contain PHB granules. Gelatinase and amylase are produced. Tween 80 is not hydrolysed. Nitrate is reduced to nitrite. Positive for the following enzyme activities as tested with the API ZYM system: alkaline and acid phosphatases, esterase (C4), esterase lipase (C8), leucine arylamidase and naphthol-AS-BI-phosphohydrolase.
Weakly positive for valine arylamidase, but negative for lipase (C14), cystine arylamidase, trypsin, $\alpha$-chymotrypsin, $\alpha$-galactosidase, $\beta$-galactosidase, $\alpha$-glucosidase, $\beta$-glucosidase, $N$-acetyl- $\beta$-glucosaminidase, $\alpha$-mannosidase, $\alpha$-fucosidase and $\beta$-glucuronidase. Utilizes acetate, L-alanine, Larabinose, L-arginine, D-glucose, myo-inositol, L-lysine, Dmannitol, peptone, L-proline, D-ribose and sucrose, but not ascorbate, DL-cysteine, dulcitol, erythritol, ethanol, glycogen, $\alpha$-ketobutyric acid, lactose, L-rhamnose, oxalic acid, raffinose or succinate as sole carbon source. Cells are sensitive to ( $\mu \mathrm{g}$ per disc) ampicillin (10), chloramphenicol (30), erythromycin (15), gentamicin (10), kanamycin (30), penicillin $G(10)$, streptomycin (10), tetracycline (30) and vancomycin (30), but resistant to nalidixic acid (30) and polymyxin B (25).

The type strain, CL-GR66 ${ }^{\mathrm{T}}\left(=\mathrm{KCCM} 90028^{\mathrm{T}}=\mathrm{DSM}\right.$ $\left.18986^{\mathrm{T}}\right)$, was isolated from coastal seawater, Korea.

\section{Acknowledgements}

We would like to thank Ms Yeon-A Jin for help with strain isolation. We also acknowledge the expert technical support of Ms In-Sung Lee (electron microscopy), National Center for Inter-University Research Facilities, Seoul National University. This work was supported in part by the BK21 project of the Korean Government and the Ministry of Maritime Affairs and Fisheries (the Korea EAST-1 program).

\section{References}

Allgaier, M., Uphoff, H., Felske, A. \& Wagner-Döbler, I. (2003). Aerobic anoxygenic photosynthesis in Roseobacter clade bacteria from diverse marine habitats. Appl Environ Microbiol 69, 5051-5059.

Altschul, S. F., Gish, W., Miller, W., Myers, E. W. \& Lipman, D. J. (1990). Basic local alignment search tool. J Mol Biol 215, 403-410.

Arahal, D. R., Macián, M. C., Garay, E. \& Pujalte, M. J. (2005). Thalassobius mediterraneus gen. nov., sp. nov., and reclassification of Ruegeria gelatinovorans as Thalassobius gelatinovorus comb. nov. Int $J$ Syst Evol Microbiol 55, 2371-2376.

Bauer, A. W., Kirby, W. M. M., Sherris, J. C. \& Turck, M. (1966). Antibiotic susceptibility testing by a standardized single disk method. Am J Clin Pathol 45, 493-496.

Biebl, H., Allgaier, M., Lünsdorf, H., Pukall, R., Tindall, B. J. \& Wagner-Döbler, I. (2005). Roseovarius mucosus sp. nov., a member of the Roseobacter clade with trace amounts of bacteriochlorophyll $a$. Int J Syst Evol Microbiol 55, 2377-2383.

Boettcher, K. J., Geaghan, K. K., Maloy, A. P. \& Barber, B. J. (2005). Roseovarius crassostreae sp. nov., a member of the Roseobacter clade and the apparent cause of juvenile oyster disease (JOD) in cultured Eastern oysters. Int J Syst Evol Microbiol 55, 1531-1537.

Bruns, A., Rohde, M. \& Berthe-Corti, L. (2001). Muricauda ruestringensis gen. nov., sp. nov., a facultatively anaerobic, appendaged bacterium from German North sea intertidal sediment. Int $J$ Syst Evol Microbiol 51, 1997-2006.

Buchan, A., González, J. M. \& Moran, M. A. (2005). Overview of the marine Roseobacter lineage. Appl Environ Microbiol 71, 5665-5677.

Cho, J.-C. \& Giovannoni, S. J. (2004). Oceanicola granulosus gen. nov., sp. nov. and Oceanicola batsensis sp. nov., poly- $\beta$-hydroxybutyrateproducing marine bacteria in the order 'Rhodobacterales'. Int J Syst Evol Microbiol 54, 1129-1136. 
Cho, J.-C. \& Giovannoni, S. J. (2006). Pelagibaca bermudensis gen. nov., sp. nov., a novel marine bacterium within the Roseobacter clade in the order Rhodobacterales. Int J Syst Evol Microbiol 56, 855-859.

Choi, D. H. \& Cho, B. C. (2006a). Shimia marina gen. nov., sp. nov., a novel bacterium of the Roseobacter clade isolated from biofilm in a coastal fish farm. Int J Syst Evol Microbiol 56, 1869-1873.

Choi, D. H. \& Cho, B. C. (2006b). Citreimonas salinaria gen. nov., sp. nov., a member of the Roseobacter clade from a solar saltern. Int J Syst Evol Microbiol 56, 2799-2803.

Cole, J. R., Chai, B., Marsh, T. L., Farris, R. J., Wang, Q., Kulam, S. A., Chandra, S., McGarrell, D. M., Schmidt, T. M. \& other authors (2003). The Ribosomal Database Project (RDP-II): previewing a new autoaligner that allows regular updates and the new prokaryotic taxonomy. Nucleic Acids Res 31, 442-443.

Collins, M. D. (1985). Analysis of isoprenoid quinones. Methods Microbiol 18, 329-366.

Dai, X., Wang, B.-J., Yang, Q.-X., Jiao, N.-Z. \& Liu, S.-J. (2006). Yangia pacifica gen. nov., sp. nov., a novel member of the Roseobacter clade from coastal sediment of the East China Sea. Int J Syst Evol Microbiol 56, 529-533.

Englen, M. D. \& Kelley, L. C. (2000). A rapid DNA isolation procedure for the identification of Campylobacter jejuni by the polymerase chain reaction. Lett Appl Microbiol 31, 421-426.

Fitch, W. M. (1971). Toward defining the course of evolution: minimum change for a specific tree topology. Syst Zool 20, 406-416.

Giovannoni, S. \& Rappé, M. (2000). Evolution, diversity and molecular ecology of marine prokaryotes. In Microbial Ecology of the Oceans, pp. 47-84. Edited by D. L. Kirchman. New York: Wiley.

Gonzalez, J. M., Mayer, F., Moran, M. A., Hodson, R. E. \& Whitman, W. B. (1997). Sagittula stellata gen. nov., sp. nov., a lignintransforming bacterium from a coastal environment. Int J Syst Bacteriol 47, 773-780.

González, J. M., Covert, J. S., Whitman, W. B., Henriksen, J. R., Mayer, F., Scharf, B., Schmitt, R., Buchan, A., Fuhrman, J. A. \& other authors (2003). Silicibacter pomeroyi sp. nov. and Roseovarius nubinhibens sp. nov., dimethylsulfoniopropionate-demethylating bacteria from marine environments. Int J Syst Evol Microbiol 53, 1261-1269.

Hansen, G. H. \& Sørheim, R. (1991). Improved method for phenotypical characterization of marine bacteria. $J$ Microbiol Methods 13, 231-241.

Jeon, Y.-S., Chung, H., Park, S., Hur, I., Lee, J.-H. \& Chun, J. (2005). jPHYDIT: a JAVA-based integrated environment for molecular phylogeny of ribosomal RNA sequences. Bioinformatics 21, 3171-3173.

Jukes, T. H. \& Cantor, C. R. (1969). Evolution of protein molecules. In Mammalian Protein Metabolism, vol. 3, pp. 21-132. Edited by H. N. Munro. New York: Academic Press.

Komagata, K. \& Suzuki, K. (1987). Lipid and cell wall analysis in bacterial systematics. Methods Microbiol 19, 161-207.

Kumar, S., Tamura, K. \& Nei, M. (2004). MEGA 3: integrated software for molecular evolutionary genetics analysis and sequence alignment. Brief Bioinform 5, 150-163.

Labrenz, M., Collins, M. D., Lawson, P. A., Tindall, B. J., Braker, G. \& Hirsch, P. (1998). Antarctobacter heliothermus gen. nov., sp. nov., a budding bacterium from hypersaline and heliothermal Ekho Lake. Int J Syst Bacteriol 48, 1363-1372.

Labrenz, M., Collins, M. D., Lawson, P. A., Tindall, B. J., Schumann, P. \& Hirsch, P. (1999). Roseovarius tolerans gen. nov., sp. nov., a budding bacterium with variable bacteriochlorophyll a production from hypersaline Ekho Lake. Int J Syst Bacteriol 49, 137-147.

Labrenz, M., Tindall, B. J., Lawson, P. A., Collins, M. D., Schumann, P. \& Hirsch, P. (2000). Staleya guttiformis gen. nov., sp. nov. and
Sulfitobacter brevis sp. nov., $\alpha$-3-Proteobacteria from hypersaline heliothermal and meromictic Antarctic Ekho Lake. Int J Syst Evol Microbiol 50, 303-313.

Lafay, B., Ruimy, R., Rausch de Traubenberg, C., Breittmayer, V., Gauthier, M. J. \& Christen, R. (1995). Roseobacter algicola sp. nov., a new marine bacterium isolated from the phycosphere of the toxinproducing dinoflagellate Prorocentrum lima. Int J Syst Bacteriol 45, 290-296.

Lane, D. J. (1991). 16S/23S rRNA sequencing. In Nucleic Acid Techniques in Bacterial Systematics, pp. 115-175. Edited by E. Stackebrandt \& M. Goodfellow. Chichester: Wiley.

Lemos, M. L., Toranzo, A. E. \& Barja, J. L. (1985). Modified medium for the oxidation-fermentation test in the identification of marine bacteria. Appl Environ Microbiol 49, 1541-1543.

Lyman, J. \& Fleming, R. H. (1940). Composition of sea water. J Mar Res 3, 134-146.

Macián, M. C., Arahal, D. R., Garay, E., Ludwig, W., Schleifer, K. H. \& Pujalte, M. J. (2005). Thalassobacter stenotrophicus gen. nov., sp. nov., a novel marine $\alpha$-proteobacterium isolated from Mediterranean sea water. Int J Syst Evol Microbiol 55, 105-110.

Marmur, J. (1961). A procedure for the isolation of deoxyribonucleic acid from microorganisms. J Mol Biol 3, 208-218.

Martens, T., Heidorn, T., Pukall, R., Simon, M., Tindall, B. J. \& Brinkhoff, T. (2006). Reclassification of Roseobacter gallaeciensis RuizPonte et al. 1998 as Phaeobacter gallaeciensis gen. nov., comb. nov., description of Phaeobacter inhibens sp. nov., reclassification of Ruegeria algicola (Lafay et al. 1995) Uchino et al. 1999 as Marinovum algicola gen. nov., comb. nov., and emended descriptions of the genera Roseobacter, Ruegeria and Leisingera. Int J Syst Evol Microbiol 56, 1293-1304.

Martínez-Cánovas, M. J., Quesada, E., Martínez-Checa, F., Del Moral, A. \& Béjar, V. (2004). Salipiger mucescens gen. nov., sp. nov., a moderately halophilic, exopolysaccharide-producing bacterium isolated from hypersaline soil, belonging to the $\alpha$-Proteobacteria. Int $J$ Syst Evol Microbiol 54, 1735-1740.

Mesbah, M., Premachandran, U. \& Whitman, W. B. (1989). Precise measurement of the $\mathrm{G}+\mathrm{C}$ content of deoxyribonucleic acid by highperformance liquid chromatography. Int J Syst Bacteriol 39, 159-167.

Minnikin, D. E., O'Donnell, A. G., Goodfellow, M., Alderson, G., Athalye, M., Schaal, K. \& Parlett, J. H. (1984). An integrated procedure for the extraction of bacterial isoprenoid quinones and polar lipids. J Microbiol Methods 2, 233-241.

Muramatsu, Y., Uchino, Y., Kasai, H., Suzuki, K. \& Nakagawa, Y. (2007). Ruegeria mobilis sp. nov., a member of the Alphaproteobacteria isolated in Japan and Palau. Int J Syst Evol Microbiol 57, 1304-1309.

Nishimura, Y., Muroga, Y., Saito, S., Shiba, T., Takamiya, K. \& Shioi, Y. (1994). DNA relatedness and chemotaxonomic features of aerobic bacteriochlorophyll-containing bacteria isolated from coasts of Australia. J Gen Appl Microbiol 40, 287-296.

Ostle, A. G. \& Holt, J. G. (1982). Nile blue A as fluorescent stain for poly- $\beta$-hydroxybutyrate. Appl Environ Microbiol 44, 238-241.

Petursdottir, S. K. \& Kristjansson, J. K. (1997). Silicibacter lacuscaerulensis gen. nov., sp. nov., a mesophilic moderately halophilic bacterium characteristic of the Blue Lagoon geothermal lake in Iceland. Extremophiles 1, 94-99.

Saitou, N. \& Nei, M. (1987). The neighbor-joining method: a new method for reconstructing phylogenetic trees. Mol Biol Evol 4, 406425.

Schaefer, J. K., Goodwin, K. D., McDonald, I. R., Murrell, J. C. \& Oremland, R. S. (2002). Leisingera methylohalidivorans gen. nov., sp. nov., a marine methylotroph that grows on methyl bromide. Int J Syst Evol Microbiol 52, 851-859. 
Smibert, R. M. \& Krieg, N. R. (1994). Phenotypic characterization. In Methods for General and Molecular Bacteriology, pp. 607-654. Edited by P. Gerhardt, R. G. E. Murray, W. A. Wood \& N. R. Krieg. Washington, DC: American Society for Microbiology.

Sorokin, D. Y., Tourova, T. P. \& Muyzer, G. (2005). Citreicella thiooxidans gen. nov., sp. nov., a novel lithoheterotrophic sulfur-oxidizing bacterium from the Black Sea. Syst Appl Microbiol 28, 679-687.

Staley, J. T., Boone, D. R., Brenner, D. J., De Vos, P., Garrity, G. M., Goodfellow, M., Krieg, N. R., Rainey, F. A. \& Schleifer, K. H. (2005). Genus XXI. Ruegeria Uchino, Hirata, Yokota and Sugiyama 1999, $1^{\mathrm{VP}}$ (Effective publication: Uchino, Hirata, Yokota and Sugiyama 1998, 208). In Bergey's Manual of Systematic Bacteriology, 2nd edn, vol. 2, part C, pp. 218-219. Edited by D. J. Brenner, N. R. Krieg, J. T. Staley \& G. M. Garrity. New York: Springer.

Suzuki, T., Muroga, Y., Takahama, M. \& Nishimura, Y. (1999). Roseivivax halodurans gen. nov., sp. nov. and Roseivivax halotolerans sp. nov., aerobic bacteriochlorophyll-containing bacteria isolated from a saline lake. Int J Syst Bacteriol 49, 629-634.

Suzuki, M., Nakagawa, Y., Harayama, S. \& Yamamoto, S. (2001). Phylogenetic analysis and taxonomic study of marine Cytophaga-like bacteria: proposal for Tenacibaculum gen. nov. with Tenacibaculum maritimum comb. nov. and Tenacibaculum ovolyticum comb. nov., and description of Tenacibaculum mesophilum sp. nov. and Tenacibaculum amylolyticum sp. nov. Int J Syst Evol Microbiol 51, 1639-1652.
Vandamme, P., Pot, B., Gillis, M., De Vos, P., Kersters, K. \& Swings, J. (1996). Polyphasic taxonomy, a consensus approach to bacterial systematics. Microbiol Rev 60, 407-438.

Woese, C. R., Stackebrandt, E., Weisburg, W. G., Paster, B. J., Madigan, M. T., Fowler, V. J., Hahn, C. M., Blanz, P., Gupta, R. \& other authors (1984). The phylogeny of purple bacteria: the alpha subdivision. Syst Appl Microbiol 5, 315-326.

Yi, H. \& Chun, J. (2006). Thalassobius aestuarii sp. nov., isolated from tidal flat sediment. J Microbiol 44, 171-176.

Yi, H., Lim, Y. W. \& Chun, J. (2007). Taxonomic evaluation of the genera Ruegeria and Silicibacter: a proposal to transfer the genus Silicibacter Petursdottir and Kristjansson 1999 to the genus Ruegeria Uchino et al. 1999. Int J Syst Evol Microbiol 57, 815-819.

Yoon, J.-H., Lee, M.-H. \& Oh, T.-K. (2004). Porphyrobacter donghaensis sp. nov., isolated from sea water of the East Sea in Korea. Int J Syst Evol Microbiol 54, 2231-2235.

Yoon, J.-H., Kang, S.-J. \& Oh, T.-K. (2007a). Donghicola eburneus gen. nov., sp. nov., isolated from seawater of the East Sea in Korea. Int $J$ Syst Evol Microbiol 57, 73-76.

Yoon, J.-H., Kang, S.-J., Lee, S.-Y. \& Oh, T.-K. (2007b). Phaeobacter daeponensis sp. nov., isolated from a tidal flat of the Yellow Sea in Korea. Int J Syst Evol Microbiol 57, 856-861. 